\title{
DISABILITY AWARENESS PADA SISWA SEKOLAH INKLUSI
}

\author{
(ka Fitria1), Dian Putri Permatasari'1), Melina Purnomo1) \\ 1)Jurusan Psikologi, Fakultas IImu Sosial dan IImu Politik, Universitas Brawijaya Malang, Malang, Jawa Timur, Indonesia \\ Corresponding author : Ika Fitria \\ E-mail : ika_fitria@ub.ac.id
}

\section{Diterima 29 Juli 2021, Direvisi 03 Agustus 2021, Disetujui 03 Agustus 2021}

\begin{abstract}
ABSTRAK
Keberadaan pendidikan inklusi menyediakan akses yang lebih besar pada kurikulum umum, meningkatkan interaksi sosial dan memiliki harapan yang lebih tinggi bagi siswa penyandang disabilitas. Namun, siswa penyandang disabilitas juga seringkali mendapatkan stigma dari teman-teman sebayanya yang dapat menimbulkan dampak kesehatan fatal, seperti meningkatkan rasa kesepian dan kecemasan dari korban, serta dapat mengurangi harga diri mereka. Peluang munculnya diskriminasi, lingkungan kelas yang negatif, atau sikap negatif dari teman sebaya bisa disebabkan karena banyak siswa yang belum mendapatkan edukasi sehingga mereka tidak mengetahui, memahami, tidak menerima, dan berempati dengan siswa penyandang disabilitas. Untuk itu, edukasi mengenai kesadaran tentang disabilitas (disability awareness) amat penting bagi sekolah karena mampu mengedukasi siswa sehingga mereka menjadi warga yang lebih baik. Berdasarkan hasil pengamatan di lapangan, ternyata masih ada siswa-siswa di SMA Muhammaddiyah 1 Malang yang belum memahami bagaimana bersikap terhadap teman disabilitas. Maka, kegiatan pengabdian kepada masyarakat dengan metode psikoedukasi ini diberikan dengan tujuan untuk meningkatkan sikap penerimaan, pemahaman, dan pengetahuan tentang disabilitas pada siswa reguler, sehingga dapat menurunkan sikap negatif terhadap siswa penyandang disabilitas. Hasil kegiatan ini menunjukkan bahwa para siswa meningkat pemahamannya mengenai konsep-konsep disabilitas. Selain itu para peserta juga memberikan tanggapan positif atas berlangsungnya kegiatan ini.
\end{abstract}

Kata kunci: kesadaran disabilitas; siswa SMA

\begin{abstract}
Inclusion education provides greater access to the general curriculum, improves social interaction and has higher expectations for students with disabilities. However, students with disabilities often got stigma from their peers which can have fatal health impacts, such as increasing loneliness and anxiety from victims, and reduce their self-esteem. The chances of discrimination, a negative classroom environment, or negative attitudes from peers can be due to many students who have not received education so they do not know, understand, accept, and empathize with students with disabilities. Therefore, education about disability awareness is very important for schools because it is able to educate students so that they become better citizens. Based on early observations in school, there are some students at SMA Muhammadiyah 1 Malang who do not understand how to behave towards friends with disabilities. Then community-oriented activity with psychoeducational method aims to improve acceptance, understanding, and knowledge of disabilities in regular students, so as to reduce negative attitudes towards students with disabilities. The results showed that students improved their understanding of the concepts of disability. In addition, the participants also gave positive responses to the activities.
\end{abstract}

Keywords: disability awareness; high school students.

\section{PENDAHULUAN}

Menurut UU RI No. 8 tahun 2016, penyandang disabilitas adalah setiap orang yang mengalami keterbatasan fisik, intelektual, mental, dan/atau sensorik dalam jangka waktu lama yang dalam berinteraksi dengan lingkungan dapat mengalami hambatan dan kesulitan untuk berpartisipasi secara penuh dan efektif dengan warga negara lainnya berdasarkan kesamaan hak. Hambatan yang dialami oleh penyandang disabilitas tidak kemudian menjadikan mereka berbeda dalam mendapatkan pendidikan. Salah satunya adalah dengan sistem pendidikan inklusi.

Pendidikan inklusi sangat penting dan mendorong pemahaman karena interaksi antara kelompok mayoritas dan minoritas merupakan langkah yang efektif untuk menghilangkan prasangka dan mendukung toleransi terhadap perbedaan (Gasser dkk., 2013). Dalam kaitannya dengan keberagaman, pendidikan dan keterlibatan merupakan hal 
yang penting dalam mengembangkan pemahaman dan penerimaan. Interaksi secara langsung maupun tidak langsung dengan anak penyandang disabilitas dapat meningkatkan sikap terhadap anak penyandang disabilitas (Armstrong dkk., 2017).

Pendidikan inklusi menyediakan akses yang lebih besar pada kurikulum umum, meningkatkan interaksi sosial dan memiliki harapan yang lebih tinggi bagi siswa penyandang disabilitas. Siswa penyandang disabilitas memiliki peluang yang lebih tinggi untuk meraih prestasi, baik secara akademik maupun sosial. Metode belajar yang beragam tidak hanya membantu siswa untuk mempelajari materi akademik tetapi juga mengembangkan berbagai kebutuhan dan kekuatan mereka (Maich \& Belcher, 2011). Kelas inklusif juga mempunyai potensi dan kesempatan terhadap masyarakat umumnya atau siswa untuk mengembangkan sikap yang lebih positif terhadap siswa penyandang disabilitas (Mrug \& Wallander, 2002; Rillotta \& Nettlebeck, 2007; Williamson, 2014). Lebih jauh, hal ini akan berdampak pada performa akademik dan kesuksesan siswa penyandang disabilitas di masa depan (Ellman, 2012).

Aspek penting dari pendidikan inklusi adalah partisipasi sosial dari semua siswa (Bossaert dkk., 2012), selain peran dari guru, orang tua, dan tenaga pendidik. Penelitian secara konsisten mendapati bahwa siswa penyandang disabilitas menunjukkan partisipasi sosial yang rendah bila dibandingkan dengan teman-teman sebayanya yang tidak mengalami disabilitas. Siswa penyandang disabilitas memiliki teman yang lebih sedikit, kurang diterima, jarang berinteraksi dengan teman-teman sebayanya sehingga mereka lebih sering merasakan kesepian (Koster et al., 2008; Schwab., 2015). Anak disabilitas juga seringkali mendapatkan stigma dari temanteman sebayanya, menghilangkan prasangka, serta mendukung toleransi terhadap perbedaan (Gasser et al., 2013). Peluang munculnya diskriminasi, lingkungan kelas yang negatif, atau sikap negatif dari teman sebaya bisa disebabkan karena banyak siswa yang belum mendapatkan edukasi sehingga mereka tidak mengetahui, memahami, tidak menerima, dan berempati dengan siswa penyandang disabilitas. Untuk itu, edukasi mengenai kesadaran tentang disabilitas (disability awareness) amat penting bagi sekolah karena mampu mengedukasi siswa sehingga mereka menjadi warga yang lebih baik (Lindsay \& Edwards, 2013). Dengan mengikutsertakan pemahaman disabilitas dan ableism (diskriminasi terhadap difabel) ke dalam pendidikan yang multikultural akan membantu siswa dalam jangka panjang dengan mengarahkan mereka di dalam prosesnya dan memberikan gambaran yang diperlukan dalam memahami keberagaman.

Sebagai solusi terhadap situasi ini, program kesadaran disabilitas mampu mendidik siswa, mendorong dan mengembangkan sikap positif khususnya bagi teman sebaya kepada siswa dengan disabilitas. Para peneliti meyakini bahwa sikap negatif terhadap individu dengan disabilitas mulai terbentuk pada awal proses perkembangan (Krahe \& Altwaser, 2006) (Lindsay \& Edwards, 2013). Amat penting untuk mengedukasi siswa ketika pada pendidikan dasar sehingga mereka dapat membawa sikap positif selama masa sekolah dan sepanjang hidup mereka. Program kesadaran merupakan salah satu upaya untuk mempromosikan sikap penerimaan, pemahaman, dan meningkatkan pengetahuan tentang perbedaan disabilitas (Ison dkk., 2010; Ramirez, 2018) sehingga dapat menurunkan sikap negatif terhadap individu dengan disabilitas. Penurunan sikap negatif merupakan kunci dalam mengembangkan penerimaan lingkungan sekolah.

Beberapa penelitian telah menemukan bahwa program "disability awareness" merupakan hal yang penting sebab dapat membawa sikap positif terhadap siswa dengan disabilitas (Morin dkk., 2013; Wang dkk., 2021). Siswa yang telah diberikan pendidikan tentang keberagaman atau disabilitas secara spesifik cenderung memiliki sikap yang lebih positif terhadap perbedaan. Sikap negatif terhadap siswa dengan disabilitas diakibatkan oleh sikap acuh atau tidak peduli (Ison dkk., 2010).

SMA Muhammadiyah 1 Kota Malang sudah mempersiapkan beberapa program untuk memfasilitasi siswa disabilitas mendapatkan pelayanan pendidikan yang sama, antara lain dengan menyiapkan modul khusus siswa difabel, membentuk paguyuban orangtua siswa difabel, dan sudah menyiapkan RPI (Rencana Pembelajaran Individu). Namun, beberapa program di atas tidak kemudian menjamin bahwa siswa penyandang disabilitas ini dapat melalui proses pendidikannya dengan baik. Tidak sedikit dari mereka yang masih mendapatkan perlakuan/sikap negatif dari teman sebaya/siswa lainnya. Diskriminasi dan perlakuan negatif ini yang membuat siswa disabilitas sering dikucilkan atau menjadi objek bual-bualan siswa lainnya. Hal ini salah satunya disebabkan karena terbatasnya pemahaman siswa mengenai disabilitas.

Oleh karena itu, melalui kegiatan pengabdian kepada masyarakat ini dilakukan psikoedukasi dengan tujuan: 
1. Siswa memperoleh informasi, pemahaman, dan kesadaran mengenai disabilitas.

2. Siswa dapat mengurangi prasangka negatif dan kesalahpahaman mengenai siswa penyandang disabilitas

3. Siswa dapat memahami bagaimana menjalani aktivitas sehari-hari dengan siswa penyandang disabilitas dan menerima perbedaan individu (individual differences).

4. Siswa dapat menunjukkan sikap yang positif pada siswa penyandang disabilitas.

Lebih jauh, melalui kegiatan ini siswa dapat memahami bahwa ketika siswa penyandang disabilitas memiliki perbedaan yang hal ini tidak berarti kehidupan mereka juga negatif. Dengan terbentuknya sikap yang lebih positif, maka akan menciptakan lingkungan sekolah inklusif bagi semua siswa. Para siswa juga dapat membawa sikap positif yang tersebut sepanjang hidup mereka nantinya.

\section{METODE}

Pengabdian Masyarakat ini bekerja sama dengan SMA Muhammadiyah 1 Malang. Psikoedukasi dilaksanakan secara online melalui google meeting pada hari kamis, 3 september 2020. Kegiatan dihadiri oleh 47 siswa dari kelas IX, X, dan XI.

Adapun langkah-langkah kegiatan pengabdian kepada masyarakat yang dilakukan adalah sebagai berikut:

\section{Persiapan}

Melakukan analisis kebutuhan dengan wawancara kepada guru sekolah SMAM 1 Malang sebagai dasar penyusunan modul psikoedukasi. Prinsip penyusunan modul yang didasarkan pada 3 tingkatan, yaitu (Loucks, Lauren Townsend, 2016):

a. Exposure: Siswa dihadapkan pada siswa dengan disabilitas melalui berbagai metode. Metode awal yang baik adalah dengan menggambarkan secara singkat disabilitas itu sendiri. Pengalaman pada tingkat ini akan membantu siswa untuk menyadari bahwa siswa berbagi karakteristik dengan siswa penyandang disabilitas.

b. Experience: Siswa diberikan kesempatan (pengalaman) untuk benarbenar mengalami disabilitas dalam waktu yang terbatas.

c. Ownership: setelah melewati dua tingkatan di awal, tingkat ketiga ini akan tercapai apabila siswa mampu menjadi pendukung bagi siswa dengan disabilitas. Siswa dapat memperlakukan siswa dengan disabilitas secara adil dan setara dalam berbagai aspek kehidupan.
2. Pelaksanaan

Kegiatan yang dilaksanakan berupa psikoedukasi dalam bentuk sosialisasi. Psikoedukasi adalah suatu intervensi yang dapat dilakukan pada individu, keluarga, dan kelompok yang fokus pada mendidik partisipannya mengenai tantangan signifikan dalam hidup, membantu partisipan mengembangkan sumbersumber dukungan dan dukungan sosial dalam menghadapi tantangan tersebut bahkan mengembangkan keterampilan coping untuk menghadapi tantangan tersebut (Anwar \& Rahmah, 2016).

Materi yang diberikan meliputi: definisi disabilitas, mitos dan fakta mengenai penyandang disabilitas, jenis disabilitas, faktor penyebab disabilitas yang semuanya disampaikan melalui media power point dan penayangan video. Selanjutnya, dilakukan role play (simulasi) yaitu siswa diajak mengalami secara langsung bagaimana seandainya mereka mengalami disabilitas dan menghayati peran sebagai siswa penyandang disabilitas. Disabilitas yang disimulasikan ada 3 yaitu autism, disabilitas intelektual, dan disabilitas fisik (gbr. 2). Setelah simulasi, siswa akan diajak berdiskusi mengenai perasaan mereka memerankan siswa penyandang disabilitas, hambatan apa saja yang mereka alami, dan sebagai teman apa yang bisa dilakukan untuk membantu.

3. Evaluasi

Terdapat dua proses evaluasi yang dilakukan yaitu: a) mengetahui peningkatan pengetahuan siswa mengenai disability awareness, b) mengetahui umpan balik kegiatan psikoedukasi.

\section{HASIL DAN PEMBAHASAN Analisis Kebutuhan}

SMA Muhammadiyah 1 Kota Malang merupakan salah satu sekolah inklusif di kota Malang. Pada tahun 2020, terdapat 10 siswa disabilitas mental yang bergabung di sekolah ini pada jenjang pendidikan kelas X, XI, dan XII. Sebagai sekolah inklusif, SMA Muhammadiyah 1 Kota Malang sudah mempersiapkan beberapa program untuk memfasilitasi siswa disabilitas untuk mendapatkan pelayanan pendidikan yang sama antara lain dengan menyiapkan modul khusus siswa difabel, membentuk paguyuban orang tua siswa difabel, dan sudah menyiapkan RPI (Rencana Pembelajaran Individu). Sekolah secara khusus juga belum pernah melakukan program mengenai kesadaran disabilitas (disability awareness) kepada siswa. Selain itu, dari wawancara singkat pada beberapa siswa 
diketahui bahwa beberapa siswa reguler masih ada yang belum memahami kenapa siswa disabilitas belajar di kelas yang sama dengannya.

\section{Pelaksanaan Program}

Kegiatan psikoedukasi mengambil tema "See the Able, NOT the Labeltumbuhkan sikap positif dalam keberagaman" . Kegiatan awalnya direncanakan akan dilakukan secara luring, tetapi karena situasi pandemi kemudian dialihkan secara daring. Kegiatan ini dihadiri oleh 47 orang siswa SMAM 1 Malang. Kegiatan berlangsung selama kurang lebih 150 menit. Pemateri dalam kegiatan ini adalah para anggota tim pengabdian Masyarakat. Kegiatan psikoedukasi dapat dilihat pada gambar 1 di bawah ini.

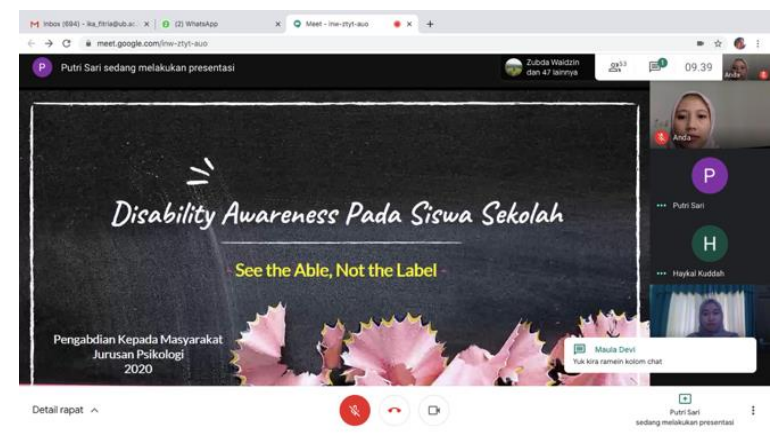

Gambar 1. Kegiatan Pengabdian kepada Masyarakat

Peserta kegiatan ini adalah siswa reguler di SMAM 1 Malang. Siswa reguler yang berada di sekolah inklusi memiliki peranan yang sangat penting untuk siswa disabilitas karena teman sebaya dapat mendukung pendidikan inklusif seperti meningkatkan penerimaan keragaman, komunikasi, keterampilan sosial, termasuk penyesuaian diri siswa disabilitas.

Kegiatan diawali dengan tanya jawab singkat mengenai mitos dan fakta yang diketahui siswa mengenai siswa disabilitas. Para peserta tampak antusias dalam mengikuti sesi ini. Setelahnya kemudian pemateri menyampaikan materi tidak hanya dalam bentuk paparan tapi juga dalam bentuk video singkat.

Selanjutnya, kegiatan dilakukan dengan metode role play (simulasi). Tujuan diadakannya roleplay ini sendiri adalah agar siswa lebih memahami bagaimana menjalani aktivitas sehari-hari sebagai siswa disabilitas dan mengurangi prasangka negatif kepada siswa disabilitas.
Jenis $\mathrm{d}$ isabilitas yang disimulasikan ada 3 yaitu autism, disabilitas intelektual, dan disabilitas fisik.Salah satu contoh penugasan yang harus dilakukan siswa dalam kegiatan role play (simulasi) terlihat di gambar 2 berikut.

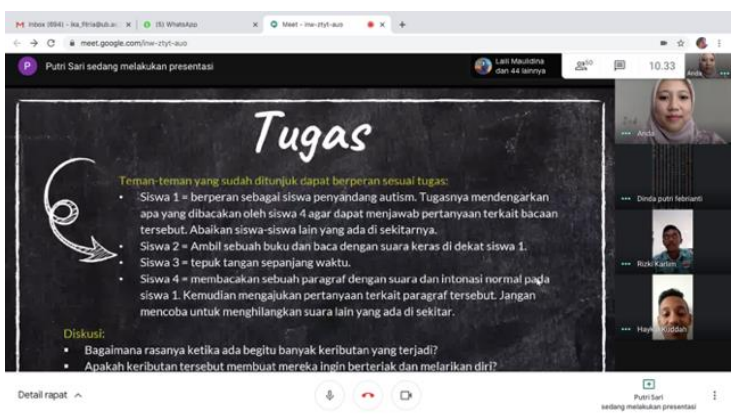

Gambar 2. Kegiatan role play (simulasi)

Selama role play, b eberapa siswa yang telah ditunjuk untuk melakukan roleplay terlihat melakukan tugasnya dengan baik, sedangkan partisipan lain yang tidak ikut dalam roleplay juga bisa menjawab dengan baik ketika ditanya bagaimana perasaan mereka apabila mereka menjadi salah satu dari beberapa siswa disabilitas tersebut, meskipun ada beberapa siswa yang mengeluhkan penjelasan materi yang diberikan terputus putus karena koneksi yang terputus.

Kegiatan psikoedukasi ditutup dengan diskusi dan kesimpulan. Siswa diminta untuk mengidentifikasi dan menuliskan hal-hal apa saja yang bisa dilakukan oleh siswa bersama dengan teman mereka (siswa penyandang disabilitas). $P$ ara siswa yang hadir diminta untuk mengisi post-test setelah sebelumnya mereka diminta mengisi post-test saat kegiatan belum dimulai.

Hasil pre-test dan post-test seperti yang terlihat di Gambar 3 menunjukkan bahwa terjadi peningkatan pengetahuan dan pemahaman para siswa (peserta) mengenai konsep disabilitas, jenis disabilitas, sekolah inklusi dan faktor penyebab disabilitas. Sebelumnya pada form hasil pre-test terdapat beberapa siswa yang masih menjawab pilihan jawaban "tidak tahu" untuk pengertian disabilitas dan jenis disabilitas, tetapi pada hasil post-test dapat diketahui tidak ada siswa yang memilih pilihan jawaban "tidak tahu". 


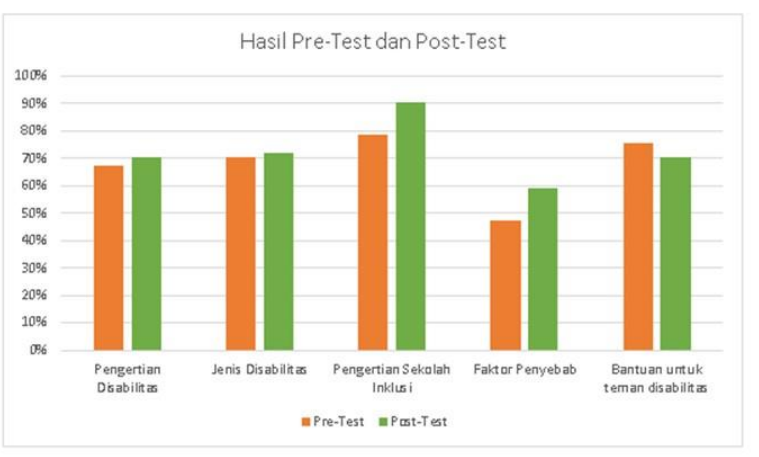

Gambar 3. Hasil Pre-post test

\section{Evaluasi Kegiatan}

Berdasarkan angket evaluasi yang diberikan kepada para peserta, sebanyak $63 \%$ peserta merasa bahwa kegiatan psikoedukasi ini sangat bermanfaat. Peserta menyampaikan bahwa melalui kegiatan ini wawasan mengenai disabilitas dan bagaimana sikap yang seharusnya dilakukan siswa saat berinteraksi dengan siswa disabilitas menjadi bertambah seperti tampak pada gambar 4 di bawah ini.
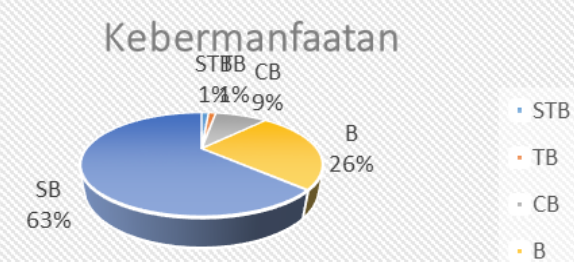

Gambar 4. Hasil angket evaluasi

Adapun saran/masukan dari peserta terkait kegiatan ini antara lain: kegiatan serupa bisa dilakukan di tahun-tahun berikutnya; psikoedukasi dilakukan tidak hanya di SMA Muhammadiyah 1 Malang saja tetapi bisa di tempat-tempat lain sehingga bullying, stigma, atau perilaku negatif terhadap siswa disabilitas bisa berkurang; kendala teknis (signal \& server yang tidak stabil) bisa diminimalisir; dan waktu sesi pertanyaan diperpanjang lagi.

\section{SIMPULAN DAN SARAN Simpulan}

Dari kegiatan pengabdian masyarakat yang telah dilakukan, dapat disimpulkan bahwa Psikoedukasi dapat menambah pengetahuan siswa terhadap disability awareness di lingkungan sekolah. Selain itu siswa mendapatkan wawasan dan tambahan informasi bagaimana membangun interaksi dan sikap yang lebih positif dengan siswa disabilitas.

\section{Saran}

Pihak sekolah SMA Muhammadiyah 1 Malang dapat meningkatkan kesadaran para siswa terhadap teman disabilitas, sehingga meningkatkan sikap dan juga perilaku positif pada para siswa disabilitas. Selain itu, pihak sekolah juga bisa mengadakan kegiatan yang melibatkan kerjasama antara siswa reguler dan siswa disabilitas sehingga siswa disabilitas mampu beradaptasi dengan lingkungan sekolah.

\section{UCAPAN TERIMAKASIH}

Terimakasih diucapkan kepada semua pihak yang telah mendukung terselenggaranya kegiatan pengabdian masyarakat melalui webinar dengan segala keterbatasan disebabkan karena pandemi Covid-19, utamanya kepada Fakultas IImu Sosial dan ilmu Politik Universitas Brawijaya selaku pemberi dana dan juga Pihak SMA Muhammadiyah 1 Malang.

\section{DAFTAR RUJUKAN}

Anwar, Z. \& Rahmah, M. (2016). Psikoedukasi tentang Resiko Perkawinan Usia Muda untuk Menurunkan Intensi Pernikahan Dini pada Remaja. Jurnal Psikologi, 1(1), $1-14$. https://doi.org/10.21070/psikologia.v1i1.7 49

Armstrong, M., Morris, C., Abraham, C. \& Tarrant, M. (2017). Interventions utilising contact with people with disabilities to improve children's attitudes towards disability: a systematic review and metaanalysis. Disability and Health Journal, 10(1), $11-22$. https://doi.org/10.1016/j.dhjo.2016.10.003

Bossaert, G., Colpin, H., Pijl, S. J. \& Petry, K. (2012). Truly included? A literature study focusing on the social dimension of inclusion in education. International Journal of Inclusive Education, 17, 60-79.

Ellman, L. (2012). Opening Eyes to the Blind: A Unit Plan that Confronts Ableism in a Standards-Based General Education Classroom. The Clearing House, 85, 1522.

Gasser, L., Malti, T. \& Buholzer, A. (2013). Children's moral judgments and moral emotions following exclusion of children with disabilities: Relations with inclusive education, age and contact intensity. Research in Developmental Disabilities, 34, 948-958.

Ison, N., McIntyre, S., Rothery, S., SmithersSheedy, H Goldsmith, S Parsonage, S. \& Foy, L. (2010). Just Like You': A Disability Awareness Programme For Children That 
Enhanced Knowledge, Attitudes And Acceptance: Pilot Study Findings. Developmental Neurorehabilitation, 13(5), 360-368.

https://doi.org/10.3109/17518423.2010.4 96764

Koster, M., Nakken, H., Pijl, S. J., Van Houten, E. \& Spelberg, H. C. L. (2008). Assessing social participation of pupils with special needs in inclusive education: The construction of a teacher questionnaire. Educational Research and Evaluation: An International Journal on Theory and Practice, 14, 395-409.

Krahe, B. \& Altwaser, C. (2006). Changing Negative Attitudes towards Persons with Physical Disabilities: An Experimental Intervention. Journal of Community \& Applied Social Psychology, 16, 56-69.

Lindsay, S. \& Edwards, A. (2013). A systematic review of disability awareness interventions for children and youth. Disability \& Rehabilitation, 35(8), 623646.

https://doi.org/10.3109/09638288.2012.7 02850

Loucks, Lauren Townsend, A. (2016). Ability Awareness Activities. https://static1.squarespace.com/static/57 152c501bbee02fa933fd7a/t/582601e929 94cabb3535090d/1478885865996/LL_AT -OAHPERD_Presentation_handout2016.pdf

Maich, K. \& Belcher, E. C. (2011). Using Picture Books to Create Peer Awareness About Autism Spectrum Disorders in the Inclusive Classroom. Intervention in School and Clinic, 47(4), 206-213. https://doi.org/10.1177/10534512114246 00

Morin, D., Rivard, M., Crocker, A., Boursier, C. \& Caron, J. (2013). Public Attitudes towards Intellectual Disability: a Multidimensional perspective. Journal of Intellectual Disability, 57(3), 279-292. https://doi.org/10.1111/jir.12008

Mrug, S. \& Wallander, L. J. (2002). SelfConcept of Young People with Physical Disabilities: does integration play a role? Journal of Disability, Development and Education, 49(3), 267-274.

Ramirez, V. P. (2018). Teaching Disability Awareness to School-Aged Children. https://digitalcommons.csumb.edu/caps_t hes_all/245

Rillotta, F. \& Nettlebeck, T. (2007). Effects Of An Awareness Program On Attitudes Of Students Without An Intellectual Disability Towards Persons With An Intellectual Disability. Journal of Intellectual \&
Developmental Disability, 32(19-29).

Schwab., S. (2015). Social dimensions of inclusion in education of 4 th and 7 th grade pupils in inclusive and regular classes: Outcomes from Austria. Research in Developmental Disabilities, 43-44, 72-79.

Wang, Z., Xu, X., Han, Q., Chen, Y., Jiang, J. \& $\mathrm{Ni}, \mathrm{G}$. (2021). Factors associated with public attitudes towards persons with disabilities: a systematic review. BMC Public Health, 21, 1-15. https://doi.org/10.1186/s12889-02111139-3

Williamson, C. (2014). Effects of Disability Awareness Educational Programs on an Effects of Disability Awareness Educational Programs on an Inclusive Classroom Inclusive Classroom Part of the Disability and Equity in Education Commons, Educational Methods Commons, and the Spec. Honors Project, 134, $1-32$. https://scholarworks.bgsu.edu/honorsproj ects 